\title{
Column
}

\section{In crisistijd leren we de ware aard kennen}

\author{
Muel Kaptein*
}

In nood leert men zijn vrienden kennen. Dit spreekwoord is vandaag de dag bij uitstek relevant voor toezichthouders. De huidige coronacrisis is namelijk een situatie van nood. Nood waar maatschappelijke belangen in het geding zijn, zoals de volksgezondheid en welvaart. Maar ook waar individuele belangen van burgers en organisaties in het geding zijn, zoals hun leven en continuiteit. In deze situatie van nood leren we niet alleen de ware aard van onder toezicht gestelden kennen maar ook van toezichthouders. Hopelijk nemen toezichthouders dit ter harte.

Het bovenstaande spreekwoord is allereerst gericht op het leren kennen van echte vrienden. Als iemand in nood is, staan de ware vrienden op. De ware vriend staat dan klaar om te helpen, om betrokkenheid te tonen, om er te zijn. Voor onder toezicht gestelden in nood is het daarom de vraag waar hun toezichthouders zijn. Want juist in nood blijkt of de toezichthouder begaan is met zijn onder toezicht gestelde. Blijft de toezichthouder er koud onder of gaat het hem aan zijn hart? Is de toezichthouder in beeld of schittert hij door afwezigheid? Natuurlijk is een toezichthouder geen allemansvriend en moet 'capture' worden voorkomen, maar dat is ook niet de strekking van het spreekwoord. De vraag is of een toezichthouder interesse toont, van zich laat horen wanneer de onder toezicht gestelde het moeilijk heeft. De crisis laat wat dat betreft zien of toezichthouders begaan zijn met hun onder toezicht gestelden.

Prof. dr. S.P. Kaptein is hoogleraar bedrijfsethiek aan de Erasmus Universiteit Rotterdam en partner bij KPMG.

\section{Opportunisme}

De crisis laat niet alleen zien of toezichthouders zijn begaan met hun onder toezicht gestelden, maar ook of toezichthouders staan voor het maatschappelijk belang dat ze behartigen. De coronacrisis raakt ook toezichthouders. Raken toezichthouders daardoor van de leg en zijn ze druk met zichzelf bezig of hebben ze oog voor wat de crisis betekent voor hun taken en werkzaamheden? Eigen aan een crisissituatie is dat er schaarste is en dat prioriteiten anders moeten worden gesteld. Als we als samenleving in de coronacrisis meer gewicht toekennen aan het beschermen van de volksgezondheid dan betekent dit dat andere maatschappelijke belangen in de hiërarchie dalen. De mate waarin een toezichthouder snel in staat is de eigen werkzaamheden te herijken, zegt veel over de kwaliteit van de toezichthouder. Krachtig was in dit verband de bekendmaking van de Autoriteit Persoonsgegevens aan het begin van de coronacrisis. $\mathrm{Zij}$ maakte toen bekend dat organisaties meer tijd van de autoriteit kregen om te reageren op vragen van de autoriteit zodat organisaties zich konden concentreren op de bestrijding van het coronavirus.

Maar om nog een andere reden is het bovengenoemde spreekwoord van belang. De vraag is ook hoe vrienden reageren als zij zelf in nood zijn. Zijn ze dan nog vrienden of haken ze af en worden ze zelfs vijandig? In nood blijkt namelijk de ware aard van mensen en organisaties. En dus ook van onder toezicht gestelden. Als de nood hoog is, blijkt waar een onder toezicht gestelde voor staat, wat zijnt echte gezicht is, wat zijn ware aard is. Juist dan blijkt of een onder toezicht gestelde echt geeft om de wetten en regels die van toepassing zijn. Want hoe langer en zwaarder een onder toezicht gestelde in nood aan de wetten en regels vasthoudt, hoe meer hij laat zien dat hij om de wetten en regels geeft. En als de onder toezicht gestelde er toch niet aan vasthoudt, dat spreekt de reden daarvoor boekdelen. Is het vanuit 
eigenbelang of omwille van andere maatschappelijke belangen? Is het vanuit pragmatisme of principes? In crisistijd blijkt dus of onder toezicht gestelden echt om wetten en regels geven.

\section{Nog niet te laat}

Toezicht in crisistijd doet derhalve een groot beroep op de integriteit van zowel toezichthouders als onder toezicht gestelden. Onder druk wordt alles vloeibaar, behalve integriteit. Naarmate de nood toeneemt, blijkt of mensen en organisaties trouw blijven aan waarvoor ze moeten staan en gaan. Voor toezichthouders betekent de crisistijd niet mínder toezicht maar ánder toezicht. Toezicht wordt relationeler, namelijk in het tonen van betrokkenheid, principiëler, namelijk naar de geest van de wet, en meer naar de aard, namelijk de integriteit van onder toezicht gestelden. Met andere woorden: het is juist in crisistijd tijd voor systeemtoezicht, toezicht op cultuur en gedrag, en toezicht op integriteit. Concepten waar in toezichtland de laatste jaren veel aandacht aan is besteed, maar waarbij het er nu op aankomt de waarde ervan te benutten en te bewijzen.

Voor toezichthouders die hiermee in crisistijd aan de slag willen maar dit nog niet hebben gedaan, is het nog niet te laat. De economische en sociale nood bij onder toezicht gestelden zal waarschijnlijk toenemen als de coronamaatregelen door de overheid worden versoepeld.

118 Als de overheidssteun wegvalt, de economische verwachtingen toenemen en het gevoel van solidariteit in de samenleving afkalft, zal de nood meer aan de man komen. Reden des te meer om er dan als toezichthouder voor de onder toezicht gestelden te zijn en vast te stellen wat hun ware aard is. 